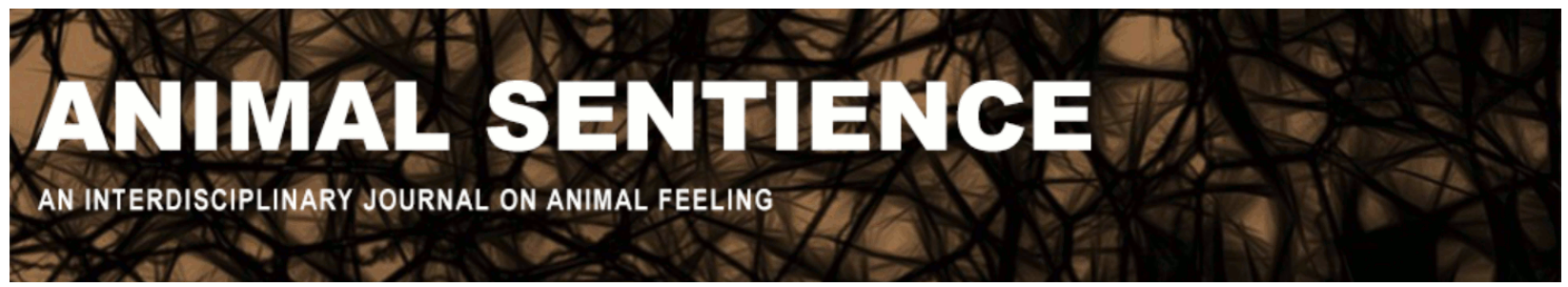

Kona-Boun, Jean-Jacques (2020) Anthropogenic suffering of farmed animals: the other side of zoonoses. Animal Sentience 30(20)

DOI: $10.51291 / 2377-7478.1207$

Date of submission: $2017-06-26$

Date of acceptance: $2020-10-16$ (c) 


\title{
Anthropogenic suffering of farmed animals: the other side of zoonoses
}

Commentary on Wiebers \& Feigin on Covid Crisis

\author{
Jean-Jacques Kona-Boun \\ Centre Vétérinaire DMV, Montréal, Québec
}

\begin{abstract}
Wiebers \& Feigin's (W\&F's) target article warns of the zoonotic threat to human health from factory farming and urges phasing out meat production and consumption, for the benefit of both human and nonhuman animals. This commentary focuses on the physical and emotional suffering of farmed animals. This varies by species, production system and geographic location, but suffering is there throughout all stages of production - breeding, housing, transport, usage and slaughter. Ubiquitous monitoring of all facilities where farmed animals are kept, with surveillance cameras recording all phases of production would help reduce some forms of suffering. Other forms are caused by accidents, disease outbreaks and all the "collateral damage" from factory farming. Nor can efforts to improve the welfare of farmed animals be confined to "merely" minimizing their suffering. Their lives need to be made not just bearable but worth living too. It is unrealistic to imagine, however, that all the suffering inflicted on farmed animals by industrial practices and human callousness can be eliminated by efforts to improve their welfare: Welfare measures urgently need to be undertaken and promoted, but they must not be regarded complacently, as if they were a panacea. A panacea would be to phase out animal production, as W\&F have proposed, under the imminent zoonotic threat of COVID-19 and its successors.
\end{abstract}

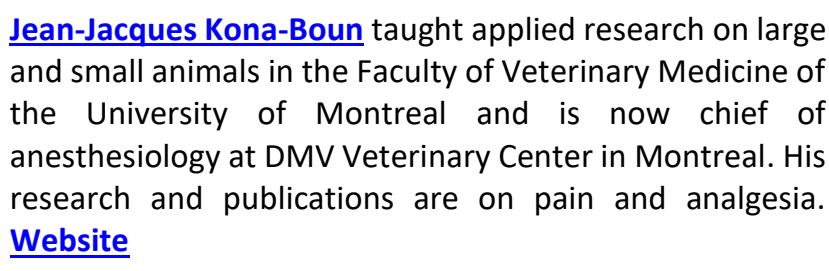

1. Introduction. Wiebers \& Feigin $(2020 a, b)$ (W\&F) point out that what COVID-19 is telling humanity is that the principal cause of present and future pandemics is zoonotic - human contact with nonhuman animals -- and that the principal solution is to phase out factory farming. W\&F note further that, as a side-benefit, this will also phase out the principle cause of animal suffering. What animal suffering is caused by factory farming? This will be the subject of this commentary.

Sentience -- the capacity for suffering, physical as well as psychological, in most nonhuman animal species -- is no longer in serious dispute (Griffin 2013; Safina 2016; Kumar et al. 2019; Birch et al. 2020). The behavioral and neural evidence that most animals (including all farmed animals except perhaps the simplest invertebrates) are sentient is abundant: the growing number of empirical studies on animal suffering provide an incontrovertible response to anyone who would still question its existence (Dawkins 2012; Broom 2016; Peggs \& Smart 2016; Ng 2016; Mellor 2016; Alonso et al. 2020). However, the true moral challenge facing our civilization may not reside in the recognition of animals' capacity for suffering; the major step that humanity must now take is to acknowledge that the exploitation of farmed animals is among the main causes of the suffering that human beings inflict on non-human animals ("anthropogenic suffering").

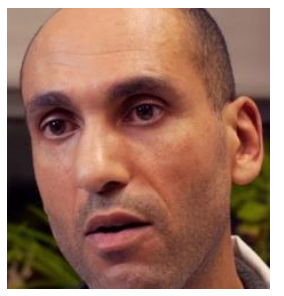


The suffering of farmed animals in the production process varies in nature and intensity depending on the species, type of farming and geographic location. Overall, suffering may be experienced in one form or another starting at birth and continues through every stage of the production process up to slaughter. Not every form of suffering is necessarily experienced in all types of farmed animals but no mode of production is entirely free of it (Farm Animal Welfare Committee 2014).

The extent of animal suffering is often downplayed by ascribing responsibility to malevolent individuals whose sadistic behaviour falls outside the norm. However, the conscious and deliberate acts of cruelty by some workers in the industry that are periodic subjects of media reports are only one subset among the many causes of suffering in farmed animals; they are neither the sole nor even the main cause. Apart from cruel acts that are punishable by law (although the law is often lenient or laxly enforced), farmed animals endure many kinds of physical and psychological suffering caused not by malicious acts but simply by standard industry practices. In a farm environment, the bulk of animal suffering is systemic (Eaton 2018; Peggs 2018). In addition to direct suffering, there is suffering that may be considered the animal production industry's collateral damage, as caused by accidents (e.g. traffic accidents, shipwrecks, farm fires; Moyer 2019) or epidemics (which lead to entire herds or flocks being put to death under suboptimal conditions; O'Sullivan 2020) or animal sports (such as rodeos [KonaBoun 2018a,b]. pig-wrestling, and poultry scrambles [Minnesota Statute 2019]). Collateral damage of this type must also be included in the catalogue of misery that is part and parcel of the animal production industry (Hodges 2003; Aerts \& de Tavernier 2016).

Animal welfare policies, which vary by jurisdiction (Blattner 2019; Vogeler 2019), aim to regulate intentional mutilating practices (such as castration, tail-docking, beak trimming, dehorning) that are common in animal production, as well as to outlaw and punish illicit malicious acts. Although such policies indisputably represent some progress on the animal cruelty front, it must be borne in mind that mutilation and malicious acts are far from the only causes of the suffering endured by farmed animals (EU Directive 1999; see below).

2. Physical suffering of farmed animals. A primary form of physical suffering inflicted on farmed animals is pain. The International Association for the Study of Pain (IASP) defines pain as "an unpleasant sensory and emotional experience associated with actual or potential tissue damage, or described in terms of such damage" (Raja et al. 2020). The emotional component of pain, which is so central to our understanding of it, has led some to challenge the applicability of this definition, originally framed for humans, to animals, on the grounds that it is not certain that animals can feel emotions, or at least not to the same degree as human beings. It has therefore been suggested that the terms "nociception" and "antinociception" are more appropriate than "pain" and "analgesia" (from the Greek an + algos, meaning "absence of pain") (Riedel et al. 2001; cf. Morris 2016; Aydede 2019).

Manfred Zimmermann (1986), an internationally respected expert on the neurobiology of pain, had formulated a definition of pain adapted to animals, based on physiological and behavioural characteristics: "An aversive sensory experience caused by actual or potential injury that elicits protective and vegetative reactions, results in learned behaviour, and may modify species specific behaviour" (Zimmermann 2005; Sneddon et al. 2018). It is now generally accepted that the animal species commonly found on farms demonstrate behaviours that 
strongly suggest the existence of emotions, whether or not they are identical to those felt by human beings. In any event, even by the most rudimentary definition, pain is at least "an aversive sensory experience." To quote the British philosopher Jeremy Bentham (1789), "The question is not, Can they reason? nor Can they talk? but, Can they suffer?" Whether animals can think is not what is at stake: the critical question is whether they can suffer, and the answer is plainly "yes." We are hence under a moral obligation to alleviate, and ideally to prevent, pain and suffering in farmed animals.

Physical suffering in farmed animals may start at birth or infancy, being sometimes associated with neonatal or infant mortality caused by human beings or by disease (Mellor \& Stafford 2004; Homedes et al. 2014). In the case of egg production, for example, the brutal destruction of male chicks, who serve no economic purpose, is a sad part of the poultry industry (Aerts et al. 2009). Newborn chicks are ground up alive or stuffed into bags to die of suffocation. Male chicks are equally useless to factory farms and to the increasingly rare traditional farms (which can no longer keep up with demand from the burgeoning human population). The death of countless male chicks is therefore a feature of all egg production, regardless of type. Ultimately, the hens too meet a grim fate at the slaughterhouse once they reach the end of their short productive lives, completely spent, after a brief existence of induced laying at an unnaturally accelerated rate (Aerts et al. 2016).

On dairy farms, male cattle are sent to the slaughterhouse at a young age, after being separated from their mothers within hours or days after birth and then often confined for the whole of their brief lives, which do not extend beyond calfhood (Ventura et al. 2013; Tuloch \& Judge 2018; Placzek et al. 2020; Mikuš \& Mikuš 2020). Females survive for several years (far less than their normal lifespan) during which they are repeatedly inseminated to gestate and give birth in order to produce enormous quantities of milk from their oversized mammary glands, the result of human manipulation designed to increase production beyond natural limits (Lehenbauer \& Oltjen 1998; Dobson et al. 2007; Sumner-Thompson et al. 2011; Ayadi 2019). Like the laying hens, dairy cows end their days at the slaughterhouse when their output falls off, as did their male calves and male siblings a few years earlier. Contrary to popular belief, eggs and milk are, just like meat, inextricably associated with inescapable suffering during the production process and ultimately the slaughter of the producing animals (Bellamy 2017; Kolbe 2018; Sanchez-Hidalgo et al. 2019; Clay et al. 2020).

Many farmed animals are also subjected to various types of mutilation, often performed without anaesthetic, sometimes in the first days of their lives (Levine et al. 2005, Janczak \& Riber 2015, Herskin et al. 2016, Canozzi et al. 2018). These mutilations -- including the removal of beaks, teeth, testicles, tails, horns, branding -- cause acute, sometimes intense, pain and can also lead to chronic pain (Breward \& Gentle 1985; Mellor et al. 2000; Angevaare et al. 2012; Nordquist et al. 2017; Casoni et al. 2019). The rationale offered for many of these practices is that they serve to protect animals against themselves and prevent the greater suffering that would otherwise arise from wounding one another. This justification, however, ignores the true source of the problem: in reality, these mutilations serve primarily to protect animals from the harmful effects of farming systems that are far removed from their natural living conditions and therefore prompt maladaptive behaviours that can result in injury (as further discussed below).

Genetic selection is used to generate greater muscle mass and body weight, and to do so at an ever-faster pace. These genetic manipulations can result in abnormalities and anatomical 
distortions, giving rise to often-painful pathologies: articular and skeletal problems such as bone deformities, pathological fractures and osteoarthritis (Gamborg \& Sandøe 2003; Bizeray et al. 2004; Shields et al. 2013; Funahashi 2020). In the case of turkeys, for example (Erasmus 2018), the enormous muscle mass and rapid growth promoted by genetic selection cause serious skeletal problems that can result in pathological fractures; the birds suffer from bone deformities and are sometimes unable to support their excessive weight or even to move (Sullivan 1994, Zampiga et al. 2020). Balance and mobility are further handicapped by the common practice of amputating the turkeys' distal toe joints to reduce injuries caused by the birds' sturdy claws (Fournier et al. 2015). Similarly, in broiler chickens (European Commission 2016, Dinev et al. 2019, Hartcher \& Lum 2020), unnaturally rapid growth and excessive muscle mass can cause pathologies including tibial dyschondroplasia and vertebral abnormalities such as spondylolisthesis, which are associated with neurological disorders (paresis, paralysis) and angular deformities of the feet (valgus, varus) (Makrai et al. 2011, Aitchison et al. 2014, Jung et al. 2018, Huang et al. 2019, Guo et al. 2019). Genetic abnormalities (Dierick et al. 2019) also cause pathologies at sites other than the arthro-skeletal system, notably hypertrophic cardiomyopathy (in both chickens and turkeys, due to too-rapid growth, high metabolic rate and excessive stress), which can lead to sudden death (Chen et al. 2017; Olkowski et al. 2020). Obstetrical problems resulting from fetopelvic disproportion occur in some species of beef cows with artificially exaggerated muscle mass, who cannot give birth naturally and must always deliver their calves, too large to pass through the pelvic canal, by caesarian section (Greger 2010; Waldner 2014; Pearson et al. 2019). And the list goes on.

Transport (often the only time in their lives when animals get a brief taste of the outdoors) may be carried out under extreme conditions of heat or cold, sometimes over prolonged periods and long distances, notwithstanding animal welfare standards (which vary from country to country and are not always enforced because of a shortage of inspectors; Webster 2001; Nalon \& Stevenson 2019; Morton et al. 2020). This often highly stressful period is also associated with physical suffering, including pain, in many cases (Elrom 2000a,b; Zanardi et al. 2007; Mitchell et al. 2009; White et al. 2009; Minka et al. 2010; Foster et al. 2014; Santurtun et al. 2015; Roy et al. 2015; Marques et al. 2016; Gaia-Eurogroup for Animals 2016; Vecerkova et al. 2019, Broom 2019). The causal factors include inadequate handling (arising from cruelty or poorly trained handlers) that can cause injuries (such as fractures in birds), the cramming of animals into transport cages or vehicles, extreme temperatures that can cause death (from hyperthermia or freezing), deprivation of food and water, and fatigue. It is not unusual for the examination of live animals at the slaughterhouse intake or of carcasses to reveal skin lesions, muscle damage or bone injuries such as contusions, hematomas, abrasions, lacerations, fractures, etc. (Bottacini et al. 2018; Dahl-Pederson et al. 2018a,b; Vecerek et al. 2019, 2010) Moreover, a non-negligible number of animals (varying by species) arrive dead (Schwartzkopf-Genswein et al. 2012, Phillips \& Santurtun 2013).

Slaughter is the fate that awaits not only animals farmed specifically for meat but also animals used for their eggs or milk, who likewise end up at the slaughterhouse at the end of their productive lives. Animals are also slaughtered for reasons other than food, such as their fur Mason et al. 2001). While slaughter is only one of the many stages of animal suffering (Veterinary Record (editorial) 2016), it is invariably the end of the road for the animals, regardless of farm type. Animals from traditional and factory farms, "organic" and standard farms, are all dispatched 
to the same slaughterhouses (Duval et al. 2020). In no type of slaughter (ritual or secular) is absence of physical suffering assured (Browning \& Veit; 2020).

Slaughter has nothing in common with euthanasia (from the Greek eu + thanatos, meaning "good death"), which implies a fast, gentle death without psychological stress or pain (or "as little as possible" -- a qualification that risks opening the door to a variety of interpretations that are not always in the animals' interest) (Kona-Boun 2005). Significant numbers of animals are likely to experience both physical and psychological suffering at slaughter, either because of the conveyance system used at the facility (e.g., fully conscious chickens suspended by the feet on hooks attached to a rail and carried upside-down to the stunning station) or because of the killing method itself. Current slaughtering techniques do not always kill or render the animal unconscious at the first attempt. Animals have been observed struggling in the vat of hot water or while being cut up (Shields \& Raj 2011; Cranley 2017; EFSA Panel on Animal Health and Welfare 2019, 2020; Sanchez-Hidalgo et al. 2019). It is impossible to guarantee the absence of physical and psychological suffering during the process, for they are concomitant with high-speed, automated slaughter (Eaton 2018; Grandin 2020; Browning \& Veit 2020). Given the speed of the slaughter lines, the process of putting animals to death cannot be individualized, in contrast with the death of a family companion animal, which is handled with care and for whom the cessation of vital functions is confirmed before the body is abandoned. Even the basest criminals sentenced to death are entitled to similar treatment. It is therefore legitimate to ask why things should be so different for farmed animals.

We can also ask why it is considered morally justifiable to sentence animals to death at all, but that is another debate. Clearly, part of the explanation lies in the consumer appetite for chicken legs and bacon, and the increase in meat consumption from burgeoning numbers of consumers (Hestermann et al. 2020). Unmonitored slaughter, with no verification that vital functions have ceased, is unconscionable in view of what comes next. Yet an individualized system would not be economically viable: it would greatly diminish productivity, drive up the already subsidized price of meat and reduce output (Grandin 2020; Broeks et al. 2020). This illustrates the inherent contradiction between animal welfare and financial considerations throughout the production process (Dawkins 2017; Hristov et al. 2019). The trade-off makes it impossible for the animal production industry to operate without causing physical and psychological suffering to the vast number of animals killed every day (Fernández-Mateo \& Franco-Barrera 2020; Zampa 2020).

3. Psychological suffering of farmed animals. The suffering of farmed animals is a multidimensional sensory and emotional experience that is by no means confined to physical sensations such as pain. Underestimating the impact of psychological suffering is a common error. When psychological suffering reaches an unbearable level, it is expressed in maladaptive behaviours (e.g. stereotypy, displacement behaviors, aggression, learned helplessness) that clearly indicate that the individual's well-being has been seriously compromised (Gunnarsson et al. 1999; Tatemoto et al. 2018; Vice 2019).

The principal forms of psychological suffering that have been studied in animals are discomfort, fear, deprivation, frustration (caused, for example, by inability to express natural behaviours in an artificial environment) and conflictual situations (Reed et al. 1993; Swanson 1995; Duncan 2004; Proudfoot, K., \& Habing, G. 2015; McMillan 2019). It is also reported that 
some species are capable of experiencing other forms of psychological suffering, such as loneliness, sadness and boredom (Meagher 2018; Nawroth et al. 2019; Cooper \& Wemelsfelder 2020). However, the psychological component of suffering in animals is often underestimated or ignored altogether. This obliviousness is sustained by the general inability to recognize behavioural signs of psychological distress in animals, which vary between species (Dantzer \& Mormède 1983; Mason 2010; Romero \& Gormally 2019; Flores-Peinado at al. 2020; Neethirian 2020; Martínez-Miró et al. 2016). Another cause is the still widespread misconception that animals are not sentient beings endowed with emotions and the ability to feel pleasure or to suffer physically and psychologically (Allen \& Bekoff 2007; Griffin 2013; Proctor et al. 2013; Birch 2017; Sneddon et al. 2018).

Psychological distress in the form of anxiety, fear, boredom, frustration or other mental states may lead to abnormal behaviour with deleterious results. One major and frequent source of psychological suffering is severe confinement, which prevents the expression of natural behaviours, some of which are powerful motivators (Moberg 2000, HSUS 2011, Mason et al. 2001; Shields \& Greger 2013; Kumar et al. 2019; Kull et al. 2019; Mee \& Boyle 2020). Confinement can also cause physical suffering when animals are unable to assume a comfortable position or are subjected to prolonged inappropriate mechanical pressure to sensitive body sites. Extreme examples of confinement systems include battery cages for laying hens, gestation crates for sows, wire cages for foxes and mink on fur farms, robotic milking installations for cows, and veal crates (Shields \& Duncan 2009; Madzingira 2018; Lascelles 2019). All these devices are associated with lack of exercise and usually lack of exposure to the outdoors, aggravating the deleterious effects. The psychological stress generated by confinement, boredom and frustration can cause maladaptive, compulsive, stereotypical behaviours, which may result in self-inflicted injury or harm to other animals (Humane Society of the United States 2011).

Public pressure has been prompting growing numbers of farms to limit the intensity and duration of some types of confinement (Cornish et al. 2016; Alonzo et al. 2020), but this pernicious feature of factory farming remains widespread. Free-range farms (Mickelson 2016) make up a negligible proportion of animal-based food product sources and are very far from being able to meet the current demand from the steadily growing human population. Nor can they ensure the elimination of all the other forms of animal suffering prevalent in the industry (Hristov et al. 2019). Even when the confinement is not to narrow cages, the overcrowding, absence of fresh air and natural sunlight, lack of outdoor access and the inability to express natural behaviors continue to cause suffering (Mellor 2019).

Psychological stress can also cause gastric erosions or ulcers in some species, or immunodepression, leaving animals more vulnerable to infection by the pathogenic microorganisms that occur in high concentrations in the crowded, confined environments common in the industry (Chmielowiec-Korzeniowska et al. 2020), as noted by W\&F and commentators Cao (2020) and Schuck-Paim (2020), The immune deficiency caused by physical and psychological stress, combined with the heavy microbial load, is then used to justify the massive use of antimicrobial drugs, one of the shared consequences of psychological and physical suffering (Mellor et al. 2000; Broom \& Kirkden 2004; Gimsa et al. 2018). This is also a breeding ground for zoonoses. To address the effects of the stressful living conditions, various types of mutilation are also practiced -- in most cases without anaesthetic (although even anesthesia can have immunological consequences: Kona-Boun, Silim \& Troncy 2005) (Aubry 2005; Prunier et al. 2005; 
Sutherland et al. 2012; Gottardo et al. 2016; Jimenez et al. 2019). Morever, such mutilations fail to address the root causes of the problem: they do nothing to alleviate the stress responsible for the aberrant behaviour; they only limit the consequences of its outward manifestations.

Perhaps the most frequently overlooked form of psychological suffering in farm environments is the distress endured in some species by mothers and their offspring because of repeated forced gestation followed by forced separation shortly after birth (Mansell et al. 2006). Separating mothers from their offspring can cause intense psychological stress in both individuals (Lay 2000, Novak et al. 2006; Newberry \& Swanson 2008; Okabe et al. 2012; Mora-Medina et al. 2015; Costa et al. 2019; Relić et al. 2020). It would be a mistake to think that only human beings feel a maternal instinct and suffer from separation. Mothering is basic, instinctive behaviour in mammals as well as birds and even some lower vertebrates; it evolved well before the emergence of Homo sapiens (Drury et al. 2016; Davis et al. 2017; Watson \& Matsuzawa 2018; Rogers \& Bales 2019; Numan 2020).

As discussed in section 2 on physical suffering, transportation often also gives rise to psychological suffering (Blecha 2000; Elrom 2000a,b; Zanardi et al. 2007; White et al. 2009; Minka et al. 2010; Foster et al. 2014; Santurtun et al. 2015; Roy et al. 2015; Marques et al. 2016; GaiaEurogroup for Animals 2016; Rioja-Lang et al. 2019; Broom 2019). Transportation has been found to be strongly associated with stress reactions, which vary by species and environmental conditions, as indicated by various behavioural and hemato-biochemical parameters and by the condition of carcasses at slaughterhouses. Sources of psychological stress include the various phases of handling, vehicle loading and unloading (the two most stressful stages of transportation, given the contact with humans, the forced physical exertion and the new, unfamiliar environment), the crowding together of unacquainted individuals, which can lead to aggression, and the trip itself, with all the physical disturbances associated with vehicular travel (caused by driving style, vibration, noise, road quality, acceleration, deceleration, braking, turns, temperature, humidity, etc.). Finally, prolonged deprivation of food and water is sometimes a significant source of psychological stress, particularly for animals accustomed to a feeding routine (Canley 2017; Damtew et al. 2018).

The psychological suffering experienced at multiple points up to and including the slaughterhouse (Duncan 2004; Faucitano \& Goumon 2018) is unmistakably expressed by, among other things, physical behaviour and vocalizations. Clearly, animals that balk at entering the corridors of death or struggle when suspended fully conscious by the hind legs, hanging upsidedown on the rail that will convey them to the puncturing point, cannot be experiencing psychological well-being.

4. Conclusion. The suffering of farmed animals is multidimensional: both sensory and emotional. It varies by species, production system and geographic location, but suffering is ubiquitous throughout all stages of production - breeding, housing, transport, usage and slaughter. The inventory of psychological and physical suffering discussed in this commentary is not exhaustive. (Farm fires, for example, not discussed here, kill tens of thousands of animals every year; their agony when burned alive cannot be excluded from the catalogue of suffering inflicted on farmed animals [Humane Society International 2020; Moyer 2020].)

Improved monitoring of all facilities where farmed animals are kept - with surveillance cameras to monitor all stages and conditions of handling, whether intentionally cruel or not - 
are important partial solutions that would help reduce some forms of suffering (Farm Animal Welfare Committee 2015; Harnad 2016; Tulloch et al. 2018; Fernández-Mateo \& Franco-Barrera, 2020). Beyond the suffering inherent in animal farming, other factors - such as fires, accidents, disease outbreaks that cause death directly or that necessitate slaughter, and the many other types of "collateral damage" suffered by the animals used in livestock production - must also be addressed.

More broadly still, whereas reducing and ultimately eliminating animal suffering is a prime objective and major challenge for the farming industry, it is also increasingly recognized that some vertebrates, including mammals and birds, have the ability to experience positive emotions and pleasure (Balcombe 2009). This suggests that efforts to improve the welfare of farmed animals cannot be confined to "merely" minimizing or abolishing their suffering (Duncan 2004; Cooper \& Wemelsfelder 2020; Dawkins 1012, 2017). Their lives need to be made not just bearable but worth living too.

It is unrealistic to imagine that all the suffering caused in farmed animals by industrial practices and human callousness can be eliminated by efforts to improve their welfare. Welfare measures (FAWC 2015) do need to be undertaken and promoted, but they must not be regarded complacently, as if they were a panacea. Let us hope that W\&F's call to phase out farmed animal production to save the human population from their mounting zoonotic threat will also save farmed animals from their mounting anthropogenic threat.

Acknowledgements: Many thanks to John Detre for translating from the French and to Nicolas Goulet for his help with the references.

\section{References}

Aaltola, E. (2012). Animal suffering: Philosophy and culture. Palgrave Macmillan.

Aerts, S; R. Boonen, V. Bruggeman, J. De Tavernier, E. Decuypere. (2009) Culling of day-old chickens: opening the debates of Moria? In: K. Millar, P. Hobson West, B. Nerlich (Eds.), Ethical Futures: Bioscience and Food Horizons, Wageningen Academic Publishers, pp 117-122.

Aerts, S., \& De Tavernier, J. (2016). Killing animals as a matter of collateral damage. In Meijboom, Franck L.B. \& Stassen, Elsbeth N. (Eds.) The end of animal life: a start for ethical debate: Ethical and societal considerations on killing animals. Wageningen Academic Publishers: 167-186

Aitchison H, Poolman P, Coetzer M, et al. (2014) Enterococcal-related vertebral osteoarthritis in South African broiler breeders: A case report. J S Afr Vet Assoc. 85:1077.

Allen, C., \& Bekoff, M. (2007). Animal consciousness. The Blackwell Companion to Consciousness, 58-71.

Alonso, M. E., González-Montaña, J. R., \& Lomillos, J. M. (2020). Consumers' concerns and perceptions of farm animal welfare. Animals, 10(3), 385.

American Veterinary Medical Association (2004) Welfare implications of teeth clipping, tail docking and permanent identification of piglets. 
Angevaare, M.J.; S. Prins, F.J. van der Staay, R.E. Nordquist. (2012) The effect of maternal care and infrared beak trimming on development, performance and behavior of Silver Nick hens. Appl. Anim. Behav. Sci., 140 pp. 70-84.

Aubry, P. (2005). Routine surgical procedures in dairy cattle under field conditions: abomasal surgery, dehorning, and tail docking. Veterinary Clinics: Food Animal Practice, 21(1), 5572.

Ayadi, M. (2019). Optimization of Milking Frequency in Dairy Ruminants. In Lactation in Farm Animals-Biology, Physiological Basis, Nutritional Requirements, and Modelization. IntechOpen.

Aydede, M. (2019). Does the IASP definition of pain need updating?. Pain Reports, 4(5).

Balcombe JP. 2009. Animal Pleasure and its Moral Significance. Applied Animal Behaviour Science 118: 208-216.

Bellamy D. (2017) Treatment of Unwanted Baby Animals. In: Steier G., Patel K. (eds) International Farm Animal, Wildlife and Food Safety Law. Springer: 151-182

Bentham, J. (1789). A utilitarian view. Animal rights and human obligations, 25-26.

Birch, J. (2017). Animal sentience and the precautionary principle. Animal Sentience, 2(16), 1.

Birch, J., Schnell, A. K., \& Clayton, N. S. (2020). Dimensions of animal consciousness. Trends in Cognitive Sciences. 24(10) 789-801.

Bizeray D, Faure JM, Leterrier C (2004) Faire marcher le poulet: pourquoi et comment. INRA Prod Anim 17(1), 45-57.

Blattner, C. E. (2019). The Recognition of Animal Sentience by the Law. Journal of Animal Ethics, 9(2), 121-136.

Blecha F (2000) Immune system response to stress. In: Moberg GP, Mench JA, eds. The biology of animal stress. Basic principles and implications for animal welfare, chapter 5.

Bottacini, M., Scollo, A., Edwards, S. A., Contiero, B., Veloci, M., Pace, V., \& Gottardo, F. (2018). Skin lesion monitoring at slaughter on heavy pigs (170 kg): Welfare indicators and ham defects. PLoS One, 13(11), e0207115.

Breward, J. ; M.J. Gentle. (1985) Neuroma Formation and Abnormal Afferent Nerve Discharges after Partial Break Amputation (Beak Trimming) in Poultry. Experientia, 41: 1132-1134.

Broeks, Marlin J., et al. (2020) A social cost-benefit analysis of meat taxation and a fruit and vegetables subsidy for a healthy and sustainable food consumption in the Netherlands. BMC Public Health 20: 1-12.

Broom D.M. (2019). Welfare of Transported Animals: Welfare Assessment and Factors Affecting Welfare, In: T. Grandin, (Ed.) Livestock Handling and Transport. CABI, pp 12-29.

Broom, DM (2016). Considering animals' feelings. Animal Sentience. 5(1).

Broom, D. M., \& Kirkden, R. D. (2004). Welfare, stress, behaviour and pathophysiology. Veterinary Pathophysiology, 337-369. 
Browning, H., \& Veit, W. (2020). Is Humane Slaughter Possible? Animals, 10(5), 799.

Canozzi, MEA., Mederos, A., Turner, SP., Manteca, X., McManus, C., Menegassi, SRO., \& Barcellos, JOJ. (2018). Dehorning and welfare indicators in beef cattle - a meta analysis. Animal Production Science, 59(5), 801- 814

Cao, Deborah (2020) Global risks of intensive animal farming and the wildlife trade. Animal Sentience 30(2)

Casoni D., Mirra A., Suter M.R., Gutzwiller A., Spadavecchia (2019). Can disbudding of calces (one versus four weeks of age) induce chronic pain? Physiology and Behavior; 199:47-55

Chen CY, Huang YF, Ko YJ, et al. (2017) Obesity-associated cardiac pathogenesis in broiler breeder hens: Development of metabolic cardiomyopathy. Poult Sci. 96: 2438-2446.

Chmielowiec-Korzeniowska, A., Trawińska, B., Tymczyna, L., Bis-Wencel, H., \& Matuszewski, Ł. (2020). Microbial contamination of the air in livestock buildings as a threat to human and animal health-a review. Annals of Animal Science, 1

Clay, N., Garnett, T., \& Lorimer, J. (2020). Dairy intensification: Drivers, impacts and alternatives. Ambio 49: 35-48.

Cooper R. \& Wemelsfelder F. (2020). Qualitative behaviour assessment as an indicator of animal emotional welfare in farm assurance. Livestock 25(4): 180-183

Cornish, A., Raubenheimer, D., \& McGreevy, P. (2016). What we know about the public's level of concern for farm animal welfare in food production in developed countries. Animals, 6(11), 74.

Costa J., Cantor M. C., Adderley N. \& Neave H. (2019) Key animal welfare issues in commercially-raised dairy calves: social environment nutrition, and painful procedures. Canadian Journal of Animal Science 99(4): 649-660

Cranley, J. (2017). Death and prolonged survival in nonstunned poultry: a case study. Journal of Veterinary Behavior, 18, 92-95.

Cranley, J. (2017). Providing water for animals at slaughter. The Veterinary Record, 181(7), 180.

Dahl-Pedersen, K., Herskin, M. S., Houe, H., \& Thomsen, P. T. (2018a). A descriptive study of the clinical condition of cull dairy cows before transport to slaughter. Livestock Science, 218, 108-113.

Dahl-Pedersen, K., Herskin, M. S., Houe, H., \& Thomsen, P. T. (2018b). Risk factors for deterioration of the clinical condition of cull dairy cows during transport to slaughter. Frontiers in Veterinary Science, 5, 297.

Damtew, A., Erega, Y., Ebrahim, H., Tsegaye, S., \& Msigie, D. (2018). The effect of long distance transportation stress on cattle: a Review. Biomedical Journal, 2, 5.

Dantzer, R., \& Mormède, P. (1983). Stress in farm animals: a need for reevaluation. Journal of Animal Science, 57(1), 6-18. 
Davis E.P., Stout. S.A., Molet J., Vegetabile B., Glynn L.M., Sandman C.A., Stern H. \& Baram T.Z.(2017). Exposure to unpredictable maternal sensory signals influences cognitive development across species, PNAS 114(39) 10390-10395

Dawkins, M. (2012). Animal suffering: the science of animal welfare. Springer Science \& Business Media.

Dawkins, M. (2017). Animal welfare and efficient farming: is conflict inevitable? Animal Production Science, 2017,57, 201-208.

Dierick, E.; O. P. Hirvonen, F. Haesebrouck, R. Ducatelle, F. Van Immerseel \& E. Goossens (2019) Rapid growth predisposes broilers to necrotic enteritis, Avian Pathology, 48(5) 416-422.

Dinev I., Kanakov D., Kalnakov I., Nikolov S. \& Denev S. (2019). Comparative Pathomorphologic Studies on the Incidence of Fractures Associated with Leg Skeletal Pathology in Commericial Broiler Chickens. Avian Diseases 63:641-650

Dobson, H; RF Smith, MD Royal, CH Knight, IM Sheldon. (2007) The high producing dairy cow and its reproductive performance. Reprod Domest Anim 42(Suppl 2): 17-23.

Drury S.S., Sanchez M. M., Gonzalez A. (2016). When mothering goes awry: Challenges and opportunities for utilizing evidence across rodent, nonhuman primate and human studies to better define the biological consequences of negative early caregiving. Hormones and Behavior 77: 182-192.

Duncan, I. J. (2005). Science-based assessment of animal welfare: farm animals. Revue Scientifique et Technique - Office International des Eepizooties, 24(2), 483.

Duncan, I.J. (2004) Pain, fear and distress. Proceedings of the Global Conference on Animal Welfare: an OIE initiative. Paris: World Organization for Animal Health.

Duval, E., von Keyserlingk, M. A., \& Lecorps, B. (2020). Organic Dairy Cattle: Do European Union Regulations Promote Animal Welfare? Animals 10(10), 1786-1808.

Eaton, A. T. (2018). Suffering of Animals in Food Production: Problems and Practical Solutions. In The Palgrave Handbook of Practical Animal Ethics (pp. 445-473). Palgrave Macmillan, London.

EFSA Panel on Animal Health and Welfare (AHAW) Nielsen, S. S., Alvarez, J., Bicout, D. J., Calistri, P., Depner, K., ... \& Miranda Chueca, M. Á. (2019). Slaughter of animals: poultry. EFSA Journal, 17(11), e05849.

EFSA Panel on Animal Health and Welfare (AHAW), Nielsen, S. S., Alvarez, J., Bicout, D. J., Calistri, P., Depner, K., ... \& Michel, V. (2020). Welfare of pigs at slaughter. EFSA Journal, 18(6), e06148.

Elrom K (2000a) Handling and transportation of broilers - Welfare, stress, fear and meat quality. Part II: stress. Israel Journal of Veterinary Medicine 55(2), 39-45.

Elrom K (2000b) Handling and transportation of broilers - Welfare, stress, fear and meat quality. Part III: fear; definitions, its relation to stress, causes of fear, responses of fear and measurement of fear. Israel Journal of Veterinary Medicine 55(3), 79-82. 
Erasmus, M. A. (2018). Welfare issues in turkey production. In Advances in Poultry Welfare (pp. 263-291). Woodhead Publishing.

EU Directive (1999). Council Directive 99/74/EC of 19 July 1999 laying down minimum standards for the protection of laying hens. Official Journal of the European Communities, 203, 53-57.

European Commission (2016). Report to the European Parliament and the Council on the Impact of Genetic Selection on the Welfare of Chickens Kept for Meat Production.

Farm Animal Welfare Committee (2014) Evidence and the welfare of farmed animals, Part 1: the evidence base.

Farm Animal Welfare Committee (2015) Welfare at slaughters, CCTV offers some real benefits in slaughterhouses, says the FAWC. Veterinary Record 176(7), 162.

Faucitano L. \& Goumon S. (2018). Transport of pigs to slaughter and associated handling. Advances in Pig Welfare. 261-293

Fernández-Mateo, J., \& Franco-Barrera, A. J. (2020). Animal Welfare for Corporate Sustainability: The Business Benchmark on Farm Animal Welfare. Journal of Sustainability Research, 2(3).

Flores-Peinado, S., Mota-Rojas, D., Guerrero-Legarreta, I., Mora-Medina, P., Cruz-Monterrosa, R., Gómez-Prado, J., ... \& Martínez-Burnes, J. (2020). Physiological responses of pigs to preslaughter handling: infrared and thermal imaging applications. International Journal of Veterinary Science and Medicine, 8(1), 71-84.

Foster SF, Overall KL (2014) The welfare of Australian farm animals transported by sea. Veterinary Journal 200(2), 205-209.

Fournier J, Schwean-Lardner K, Knezacek TD, Gomis S, Classen HL. (2014) The effect of toe trimming on production characteristics of heavy turkey toms. Poult Sci. 93: 2370-2374.

Funahashi, H. (2020). Animal Biotechnology Roles in Livestock Production. In IOP Conference Series: Earth and Environmental Science 465(1): 012001). IOP Publishing.

Gaia, Eurogroup for Animals (2016) Fact file : long distance farm animals transports.

Gamborg, C., \& Sandøe, P. (2003). Breeding and biotechnology in farm animals-ethical issues. Key issues in bioethics. Routledge, London, 133-142.

Gimsa, U., Tuchscherer, M., \& Kanitz, E. (2018). Psychosocial stress and immunity-what can we learn from pig studies?. Frontiers in Behavioral Neuroscience, 12, 64.

Gottardo, F., Scollo, A., Contiero, B., Ravagnani, A., Tavella, G., Bernardini, D., ... \& Edwards, S. A. (2016). Pain alleviation during castration of piglets: a comparative study of different farm options. Journal of Animal Science, 94(12), 5077-508

Grandin T. (2020). Tradeoffs Balancing Livestock and Poulty Welfare Concerns with the Commercial Reality of Slaughter. In T. Grandin \& M. Cockram (Eds.) The Slaughter of Farmed Animals: Practical Ways of Enhancing Animal Welfare CABI pp. 35-48 
Greger, M. (2010). Trait selection and welfare of genetically engineered animals in agriculture. Journal of Animal Science, 88(2), 811-814.

Griffin, D. R. (2013). Animal minds: Beyond cognition to consciousness. University of Chicago Press.

Gunnarsson, S.; L.J. Keeling, J. Svedberg. (1999) Effect of rearing factors on the prevalence of floor eggs, cloacal cannibalism and feather pecking in commercial flocks of loose housed laying hens. Br. Poult. Sci. 40: 12-18.

Guo, Y., Tang, H., ... \& Han, R. (2019). Clinical assessment of growth performance, bone morphometry, bone quality, and serum indicators in broilers affected by valgus-varus deformity. Poultry Science, 98(10), 4433-4440.

Hammond, J., \& Day, F. T. (1944). Oestrogen treatment of cattle: induced lactation and other effects. Journal of Endocrinology, 4(4), 53-NP.

Harnad, S. (2016). CCTV, web-streaming and crowd-sourcing to sensitize public to animal suffering. Animal Justice UK, 2.

Hartcher, K. M., \& Lum, H. K. (2020). Genetic selection of broilers and welfare consequences: a review. World's Poultry Science Journal, 76(1), 154-167.

Herskin MS, Di Giminiani P, Thodberg K (2016) Effects of administration of a local anaesthetic and/or an NSAID and of docking length on the behaviour of piglets during $5 \mathrm{~h}$ after tail docking. Research in Veterinary Science 108, 60-67.

Hestermann, N., Le Yaouanq, Y., \& Treich, N. (2020). An economic model of the meat paradox. European Economic Review, 103569.

Hodges, J. (2003). Livestock, ethics, and quality of life. Journal of Animal Science, 81(11), 28872894.

Homedes J, Salichs M, Sabaté D et al. (2014) Effect of ketoprofen on pre-weaning piglet mortality on commercial farms. Veterinary Journal 201(3), 435-437.

Hristov S.V., Stanković B.M., Andrić D.N.O., Maksimović N. Lj., Nakov D.D. (2019). The most important dilemmas regarding the welfare of farm animals. Journal of Agricultural Sciences 64(4): 319-340.

Huang S, Kong A, Cao Q, Tong Z, Wang X. (2019) The role of blood vessels in broiler chickens with tibial dyschondroplasia. Poult Sci. 98: 6527-6532.

Humane Society International (HSI) (2020) Untold Suffering: The Tragic Impact of Barn Fires on Animals. A Five-Year Review of Barn Fires in Canada.

Humane Society of the United States (2011) An HSUS report: welfare issues with gestation crates for pregnant sows. HSUS Reports: Farm Industry Impacts on Animals. Paper 25.

Janczak AM, Riber AB. (2015) Review of rearing-related factors affecting the welfare of laying hens. Poultry Science 94: 1454-1469. 
Jimenez, R. E., Adcock, S. J., \& Tucker, C. B. (2019). Acute pain responses in dairy calves undergoing cornual nerve blocks with or without topical anesthetic. Journal of Dairy Science, 102(4), 3431-3438.

Jung A, Chen LR, Suyemoto MM, Barnes HJ, Borst LB. (2018) A Review of Enterococcus cecorum Infection in Poultry. Avian Dis. 62: 261-271.

Kaiser, P. (2018). Don't be cruel: the significance of cruelty in the current meat-debate. In Springer, Svenja \& Grimm, Herwig (Eds.) Professionals in food chains. Wageningen Academic Publishers: 157-162.

Kolbe, K. (2018). Why Milk Consumption is the Bigger Problem: Ethical Implications and Deaths per Calorie Created of Milk Compared to Meat Production. J Agric Environ Ethics 31 : 467-481

Kona-Boun, J. J. (2005). L'euthanasie: principes fondamentaux. Dans le cadre du cours DMV, $3132,223-233$.

Kona-Boun, J. J., Silim, A., \& Troncy, E. (2005). Immunologic aspects of veterinary anesthesia and analgesia. Journal of the American Veterinary Medical Association, 226(3), 355-363.

Kona-Boun, J.J. (2017a) Salient facts. In: Roy, A. (2017) Report on the Analysis of the Data Collected During the Montreal and St-Tite Rodeos in Montreal (August and September 1917) pp. 7-36.

Kona-Boun, J.J. (2017b) Analyses. In: Roy, A. (2017) Report on the Analysis of the Data Collected During the Montreal and St-Tite Rodeos in Montreal (August and September 1917) pp. 37-358.

Kull, J. A., Proudfoot, K. L., Pighetti, G. M., Bewley, J. M., O’Hara, B. F., Donohue, K. D., \& Krawczel, P. D. (2019). Effects of acute lying and sleep deprivation on the behavior of lactating dairy cows. PloS One, 14(8), e0212823.

Kumar, S., Sanjay C., Rohit K., Alok K., Prasanna P. and Kanika M. (2019). Animal sentience and welfare: an overview. Int. J. Curr.Microbiol. App. Sci. 8(8): 635-646.

Lascelles, R. (2019). The Oxymoron of Caged Animal Welfare: A Case Study in The Australian Caged Rabbit Meat Industry. In: Derecho Animal: Forum of Animal Law Studies 10(2): 107-208.

Lay DC (2000) Consequences of stress during development. In: Moberg GP, Mench JA, eds. The biology of animal stress. Basic principles and implications for animal welfare, chapter 12.

Lehenbauer T.W., Oltjen J.W. (1998) Dairy cow culling strategies: Making economical culling decisions. J. Dairy Sci. 81: 264-271.

Levine ED, Mills DS, Houpt KA (2005) Attitudes of veterinary students at one US college toward factors relating to farm animal welfare. Journal of Veterinary Medicine Education 32(4), 481-490.

Madzingira, O. (2018). Animal Welfare Considerations in Food-Producing Animals. In: Abubakar, M. \& Manzoor, S. (Eds.) Animal Welfare IntechOPen 
Makrai L, Nemes C, Simon A, et al. (2011) Association of Enterococcus cecorum with vertebral osteomyelitis and spondylolisthesis in broiler parent chicks. Acta Vet Hung. 59: 11-21.

Mansell, P. D., Cameron, A. R., Taylor, D. P., \& Malmo, J. (2006). Induction of parturition in dairy cattle and its effects on health and subsequent lactation and reproductive Performance. Australian Veterinary Journal 84: 312-6

Marques AT, Lecchi C, Grilli G et al. (2016) The effect of transport stress on turkey (meleagris gallopavo) liver acute phase proteins gene expression. Research in Veterinary Science 104, 92-95.

Martínez-Miró, S., Tecles, F., Ramón, M., Escribano, D., Hernández, F., Madrid, J., ... \& Cerón, J. J. (2016). Causes, consequences and biomarkers of stress in swine: an update. BMC Veterinary Research, 12(1), 171.

Mason, G. J. (2010). Species differences in responses to captivity: stress, welfare and the comparative method. Trends in Ecology \& Evolution, 25(12), 713-721.

Mason, G. J., Cooper, J., \& Clarebrough, C. (2001). Frustrations of fur-farmed mink. Nature, 410(6824), 35-36.

McMillan, F.D. (2019) "The Mental Health and Well-being Benefits of Social Contact and Social Support in Animals. In: McMillan, F.D (ed.) Mental Health and Well-being in Animals. 96.

Meagher, R. (2018). Is boredom an animal welfare concern? Animal Welfare, 28(1): 21-32.

Mee, J. F., \& Boyle, L. A. (2020). Assessing whether dairy cow welfare is "better" in pasturebased than in confinement-based management systems. New Zealand Veterinary Journal, 68(3), 168-177.

Mellor, D. J. (2019). Welfare-aligned sentience: Enhanced capacities to experience, interact, anticipate, choose and survive. Animals, 9(7), 440.

Mellor, D. J. (2016). Updating animal welfare thinking: Moving beyond the "Five Freedoms" towards "a Life Worth Living". Animals, 6(3), 21.

Mellor DJ, Cook CJ, Stafford KJ (2000) Quantifying some responses to pain as a stressor. In: Moberg GP, Mench JA, eds. The biology of animal stress. Basic principles and implications for animal welfare, chapter 9.

Mellor, D. J., \& Stafford, K. J. (2004). Animal welfare implications of neonatal mortality and morbidity in farm animals. The Veterinary Journal, 168(2), 118-133.

Mickelson, T. (2016). Free-Range Farming. Lerner Publications.

Mikuš, T., \& Mikuš, O. (2020). Early weaning: new insights on an ever-persistent problem in the dairy industry. Journal of Dairy Research, 87(S1), 88-92.

Minnesota Statute 343.36 (2019) Greased pig contests and turkey scrambles.

Mitchell MA, Kettlewell PJ (2009) Welfare of poultry during transport - A review. Poultry Welfare Symposium Cervia, Italy, 18-22 May 2009. 
Moberg GP (2000) Biological response to stress: implications for animal welfare. In: Moberg GP, Mench JA, eds. The biology of animal stress. Basic principles and implications for animal welfare, chapter 1.

Mora-Medina, P., Mota-Rojas, D., Arch-Tirado, E., \& Orozco-Gregorio, H. (2015). Animal welfare in lambs: ewe-lamb separation. Large Animal Review, 21(1), 39-44.

Morris D.B. (2016) Animal Pain: The Limits of Meaning. In: van Rysewyk S. (eds) Meanings of Pain. Springer

Morton, R., Hebart, M. L., \& Whittaker, A. L. (2020). Explaining the Gap Between the Ambitious Goals and Practical Reality of Animal Welfare Law Enforcement: A Review of the Enforcement Gap in Australia. Animals, 10(3), 482.

Moyer, W. (2020) From barn fires to hurricanes: Helping animals in times of crisis. BEVA Equine Veterinary Education 32(8): 397

Nalon, E., \& Stevenson, P. (2019). Addressing Lameness in Farmed Animals: An Urgent Need to Achieve Compliance with EU Animal Welfare Law. Animals, 9(8), 576.

Nawroth C, Langbein J, Coulon M, Gabor V, Oesterwind S, Benz-Schwarzburg J and von Borell E (2019) Farm Animal Cognition - Linking Behavior, Welfare and Ethics. Front. Vet. Sci. $6: 24$.

Neethirajan, S. (2020). Transforming the Adaptation Physiology of Farm Animals through Sensors. Animals, 10(9), 1512.

Newberry, R. C., \& Swanson, J. C. (2008). Implications of breaking mother-young social bonds. Applied Animal Behaviour Science, 110(1-2), 3-23.

$\mathrm{Ng}$, Y. K. (2016). How welfare biology and commonsense may help to reduce animal suffering. Animal Sentience 7(1)

Nordquist, R.E.; Van der Staay, F.J.; Van Eerdenburg, F.J.C.M.; Velkers, F.C.; Fijn, L.; Arndt, S.S. (2017). Mutilating Procedures, Management Practices, and Housing Conditions That May Affect the Welfare of Farm Animals: Implications for Welfare Research. Animals, 7, 12

Novak MA, Meyer JS, Lutz C et al. (2006) Deprived environment: developmental insights from primatology. In: Mason G, Rushen J, eds. Stereotypic animal behaviour. Fundamentals and applications to welfare. Second edition, 2006, chapter 6.

Numan, M. (2020). The Parental Brain: Mechanisms, Development, and Evolution. Oxford University Press.

O'Sullivan, V. (2020). Non-human animal trauma during the pandemic. Postdigital Science and Education, 1-9.

Okabe, S., Nagasawa, M., Mogi, K., \& Kikusui, T. (2012). The importance of mother-infant communication for social bond formation in mammals. Animal Science Journal, 83(6), 446-452.

Olkowski , A. A.; C. Wojnarowicz \& B. Laarveld (2020) Pathophysiology and pathological 
remodelling associated with dilated cardiomyopathy in broiler chickens predisposed to heart pump failure. Avian Pathology, 49(5), 428-439

Pearson JM, Homerosky ER, Caulkett NA, et al. (2019) Quantifying subclinical trauma associated with calving difficulty, vigour, and passive immunity in newborn beef calves. Vet Rec Open. 6:e000325.

Peggs, K. (2018). Animal Suffering Matters. In The Palgrave Handbook of Practical Animal Ethics (pp. 373-393). Palgrave Macmillan, London.

Peggs, K., \& Smart, B. (2017). Nonhuman Animal Suffering. Society \& Animals, 25(2), 181-198.

Phillips CJ \& Santurtun E. (2013) The welfare of livestock transported by ship. Vet J. 196: 309314.

Placzek, M., Christoph-Schulz, I., \& Barth, K. (2020). Public attitude towards cow-calf separation and other common practices of calf rearing in dairy farming-a review. Organic Agriculture, 1-10.

Proctor, H. S., Carder, G., \& Cornish, A. R. (2013). Searching for animal sentience: A systematic review of the scientific literature. Animals 3(3), 882-906.

Proudfoot, K., \& Habing, G. (2015). Social stress as a cause of diseases in farm animals: current knowledge and future directions. The Veterinary Journal, 206(1), 15-21.

Prunier, A., Mounier, A. M., \& Hay, M. (2005). Effects of castration, tooth resection, or tail docking on plasma metabolites and stress hormones in young pigs. Journal of Animal Science, 83(1), 216-222.

Raja, S. N., Carr, D. B., Cohen, M., Finnerup, N. B., Flor, H., Gibson, S., ... \& Song, X. J. (2020). The revised International Association for the Study of Pain definition of pain: concepts, challenges, and compromises. Pain, 161(9), 1976-1982.

Reed, H.J.; L.J. Wilkins, S.D. Austin, N.G. Gregory. (1993) The effect of environmental enrichment during rearing on fear reactions and depopulation trauma in adult caged hens. Appl Anim Behav Sci 36: 39-46.

Relić R, Starič J and Ježek J(2020). Management practices that influence the welfare of calves on small family farms. Journal of Dairy Research 87(S1), 93-98.

Riedel, W., \& Neeck, G. (2001). Nociception, pain, and antinociception: current concepts. Zeitschrift für Rheumatologie, 60(6), 404-415.

Rioja-Lang, F. C., Brown, J. A., Brockhoff, E. J., \& Faucitano, L. (2019). A review of swine transportation research on priority welfare issues: a Canadian perspective. Frontiers in Veterinary science, 6, 36.

Rogers F.D. \& Bales K.L. (2019). Mothers, Fathers and Others: Neural Substrates of Parental Care. Trends in Neurosciences 42(8):552-562

Romero, L. M., \& Gormally, B. M. (2019). How truly conserved is the "well-conserved" vertebrate stress response? Integrative and comparative biology, 59(2), 273-281. 
Roy RC, Cockram MS (2015) Patterns and durations of journeys by horses transported from the USA to Canada for slaughter. Canadian Veterinary Journal 56, 581-586.

Safina, Carl (2016) Animals think and feel. Animal Sentience 2(1)

Sánchez-Hidalgo M., Rosenfeld C. \& Gallo C. (2019). Associations between Pre-Slaughter and Post-Slaughter Indicators of Animal Welfare in Cull Cows. Animals 9(9) 642.

Santurtun E, \& Phillips CJC (2015) The impact of vehicle motion during transport on animal welfare. Research in Veterinary Science 100, 303-308.

Schuck-Paim, Cynthia (2020) Intensive animal farming conditions are a major threat to global health. Animal Sentience 30(8)

KS, Faucitano L, Dadgar S, Shand P, González LA, Crowe TG. (2012) Road transport of cattle, swine and poultry in North America and its impact on animal welfare, carcass and meat quality: a review. Meat Sci. 92: 227-243.

Shields S \& Greger M (2013) Animal welfare and food safety aspects of confining broiler chickens to cages. Animals 3, 386-400.

Shields, S., \& Duncan, I. J. (2009). An HSUS Report: A comparison of the welfare of hens in battery cages and alternative systems.

Shields SJ \& Raj AB (2011) A critical review of electrical water-bath stun systems for poultry slaughter and recent developments in alternative technologies. J Appl Anim Welf Sci. 13: 281-299. [published correction appears in J Appl Anim Welf Sci. 2011 14: 371]

Sneddon, Lynne U.; Lopez-Luna, Javier; Wolfenden, David C.C.; Leach, Matthew C.; Valentim, Ana M.; Steenbergen, Peter J.; Bardine, Nabila; Currie, Amanda D.; Broom, Donald M.; and Brown, Culum (2018) Fish sentience denial: Muddying the waters. Animal Sentience 21(1)

Statute Minka NS, Ayo JO (2010) Physiological responses of food animals to road transportation stress. African Journal of Biotechnology 9(40), 6601-6613.

Sullivan TW. (1994) Skeletal problems in poultry: estimated annual cost and descriptions. Poult Sci. 73: 879-882.

Sumner-Thomson, J. M., Vierck, J. L., \& McNamara, J. P. (2011). Differential expression of genes in adipose tissue of first-lactation dairy cattle. Journal of Dairy Science, 94(1), 361-369.

Sutherland, M. A., Davis, B. L., Brooks, T. A., \& Coetzee, J. F. (2012). The physiological and behavioral response of pigs castrated with and without anesthesia or analgesia. Journal of Animal Science, 90(7), 2211-2221.

Swanson, J. C. (1995). Farm animal well-being and intensive production systems. Journal of Animal Science, 73(9), 2744-2751.

Tatemoto P, Bernardino T, Morrone B, Queiroz MR and Zanella AJ (2020) Stereotypic Behavior in Sows Is Related to Emotionality Changes in the Offspring. Front. Vet. Sci. 7:79. 
Tulloch, L., \& Judge, P. (2018). Bringing the calf back from the dead: video activism, the politics of sight and the New Zealand dairy industry. Video Journal of Education and Pedagogy, 3(1), 1-20.

Vecerek, V., Vecerkova, L., \& Voslarova, E. (2019). Comparison of the frequency of pathoanatomic findings in laying hens with findings in broiler chickens and turkeys detected during post-mortem veterinary inspection. Poultry Science, 98(11), 5385-5391.

Vecerek, V., Voslarova, E., Semerad, Z., \& Passantino, A. (2020). The Health and Welfare of Pigs from the Perspective of Post Mortem Findings in Slaughterhouses. Animals, 10(5), 825.

Vecerkova, L., Vecerek, V., \& Voslarova, E. (2019). Welfare of end-of-lay hens transported for slaughter: effects of ambient temperature, season, and transport distance on transportrelated mortality. Poultry Science, 98(12), 6217-6224.

Ventura, B. A., Von Keyserlingk, M. A. G., Schuppli, C. A., \& Weary, D. M. (2013). Views on contentious practices in dairy farming: The case of early cow-calf separation. Journal of Dairy Science, 96(9), 6105-6116.

Veterinary Record (editorial) (2016) Investigation reveals daily breaches of welfare regulations in slaughterhouses, Veterinary Record 179(10), 240.

Vice, A. (2019). Stereotypies and Other Abnormal Behavior in Welfare Assessment. Encyclopedia of Animal Behavior, 141.

Vogeler, C. S. (2019). Why do farm animal welfare regulations vary between EU member states? A comparative analysis of societal and party political determinants in France, Germany, Italy, Spain and the UK. JCMS: Journal of Common Market Studies, 57(2), 317-335.

Waldner CL. (2014) Cow attributes, herd management and environmental factors associated with the risk of calf death at or within $1 \mathrm{~h}$ of birth and the risk of dystocia in cow-calf herds in Western Canada. Livest Sci 163: 126-39.

Watson CFI \& Matsuzawa T. (2018) Behaviour of nonhuman primate mothers toward their dead infants: uncovering mechanisms. Philosophical Transactions of the Royal Society B: Biological Sciences, 373(1754), 20170261.

Webster, A. J. (2001). Farm animal welfare: the five freedoms and the free market. The Veterinary Journal, 161(3), 229-237.

White BJ, Blasi D, Vogel LC et al. (2009) Associations of beef calf wellness and body weight gain with internal location in a truck during transportation. Journal of Animal Science 87, 4143-4150.

Wiebers, D.O. \& Feigin, V.L. (2020a) What the COVID-19 crisis is telling humanity. Neuroepidemiology, 54, 283-286.

Wiebers, D.O. \& Feigin, V.L. (2020b) What the COVID-19 crisis is telling humanity. Animal Sentience 30 (1).

Wilson, D. J., Stojkov, J., Renaud, D. L., \& Fraser, D. (2020). Condition of male dairy calves at auction markets. Journal of Dairy Science 103(9): 8530-8534. 
Zampa, M. (2020). How Many Animals Are Killed for Food Every Day? Sentient Media.

Zampiga M., Soglia F., Giula B., Massimiliano P., Strasburg G.M., Sirri F. (2020), Muscle Abnormalities and Meat Quality Consequences in Modern Turkey Hybrids. Frontiers in Physiology 11: 554

Zanardi E, Mussini V, Ghidini S et al. (2007) Survey on animal welfare and protection during transport in northern Italy. Annali della Facolta di Medicina Veterinaria, Universita di Parma 27, 33-42.

Zimmerman, M. (1986). Physiological mechanisms of pain and its treatment. Klinische Anaesthesiol Intensivether, 32, 1-19.

Zimmermann M. (2005) The history of pain concepts and treatment before IASP. In: Merskey H, Loeser JD, Dubner R (eds.). The paths of pain 1975-2005. Seattle: IASP Press, 2005. p. 121. 